\author{
Z. J. Dolatowski, J. Stadnik \\ Agricultural University of Lublin, Poland

\section{EFFECT OF SONICATION ON TECHNOLOGICAL PROPERTIES OF BEEF}

\begin{abstract}
Ultrasound treatment during rigor mortis period led to an acceleration of aging processes. No significant influence of sonication on acidity during ageing was observed. Ultrasound treatment did not influence the lightness, but according to the shear force measurements, improve meat tenderness. Differentiated technological properties of examined samples may result from influence of ultrasound on protein structures of meat. As a result of ultrasound treatment an increase of free calcium ions concentration occurred. Obtained results pointed out that sonication may be an effective method of formation of technological properties of beef during ageing.
\end{abstract}

Обробка м'яса ультразвуком у період трупного задубіння призводить до прискорення процесів старіння (пом'якшення тканин). Ця обробка істотно не впливала на кислотність тканини та на втрату ваги, але поліпшувала ніжність м'яса. Визначені технологічні властивості досліджених зразків можуть бути наслідком впливу ультразвуку на структуру білків м'яса. Внаслідок обробки ультразвуком відбулося збільшення концентрації вільних іонів кальцію. Отримані результати показали, що обробка ультразвуком може бути ефективним методом формування технологічних властивостей яловичини.

\title{
Introduction
}

Meat quality is assessed from the point of view of its technological and culinary properties. One of the most important features during technological evaluation of meat is its tenderness. Meat tenderness is highly affected by post mortem changes of myofibrils. Rigor onset followed by degradation of myofibrils structure affects water holding capacity (WHC), cooking loss and consequently its tenderness. Formation of technological properties of meat is a complicated, yet very important stage of its processing. One of the methods for modifying meat properties is its subjection to ultrasound treatment directly after slaughter or during rigor mortis period $[1 ; 9]$.

Attempts have been made to apply ultrasound waves during meat ageing. Application of ultrasound to provoke changes of physical and chemical properties of meat attracts the interest of research workers as a pure physical technique, providing an alternative to chemical means of processing [3]. Interest in ultrasound applications is connected with the effects of its use on biological materials $[4 ; 8-10 ; 15 ; 17]$. Muscle tissue is a special area for ultrasound propagation. Results of previous research show that ultrasound treatment has an influence on meat ageing, especially on myofibrillar proteins [2; 7].

The aim of research was to investigate the influence of ultrasound treatment on technological properties of beef during its ageing.

\section{Materials and Methods}

Investigations were carried out on young bulls (Lowland Black and White Breed) slaughtered at a live weight of approximately $450-500 \mathrm{~kg}$ following standard procedure. The muscles ( $m$. semimembranosus), free from quality defects, were excised at 24 hour post mortem from left half-carcasses of temperature $7^{\circ} \mathrm{C}$. Muscle, free of external fat and connective tissue, was divided into eight blocks, $(70 \times 70 \times 80 \mathrm{~mm}$, length, width and height, respectively) of about $400 \mathrm{~g}$.

(C) Z. J. Dolatowski, J. Stadnik, 2007

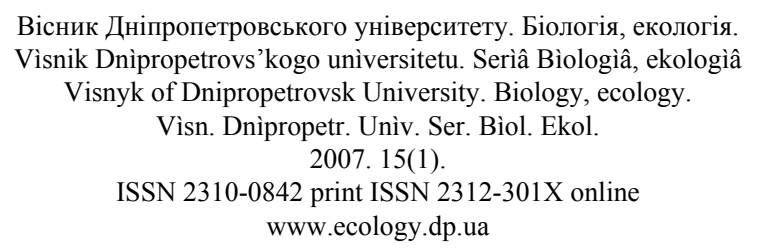


Four of the parts were regarded as control samples (C). The other four were subjected to ultrasound treatment with frequency of $45 \mathrm{kHz}$ (sample U). In order to carry out ultrasound treatment samples packed in polyethylene bags were placed into an ultrasound bath (Polsonic, Warsaw, Poland) filled with cold water $\left(4^{\circ} \mathrm{C}\right)$ and then sonicated. The low intensity ultrasonic field $\left(2 \mathrm{~W} / \mathrm{cm}^{2}\right)$ was applied perpendicularly to muscle fibers for $120 \mathrm{~s}$. Meat samples were then stored at $4^{\circ} \mathrm{C}$ until assessed. Directly after ultrasound treatment and then daily for a total of 4 days the following characteristics were tested: acidity, water holding capacity [19], lightness L $^{*}$ (X-Rite 8200), free calcium ions concentration by ASA method [5] and shear force (TA-XT plus; Stable Micro Systems).

Three series of experiments and three replications of each experiment were conducted. Obtained results were subjected to statistical analysis $(p=0.05)$.

\section{Results and discussion}

Based on the statistical analysis of obtained results, it was found that there were no significant differences between acidity values of both samples directly after sonication as well as after 72 and 96 hours of storage (fig. 1). Directly after ultrasound treatment differences in water holding capacity between examined samples were not significant (fig. 2).

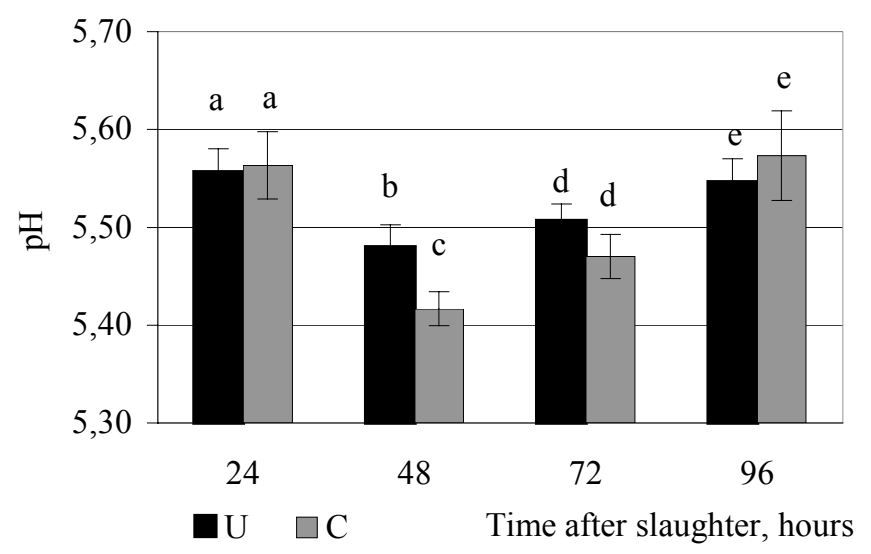

Fig. 1. Influence of ultrasound treatment on acidity of meat: means followed by the same letters $a-e$ do not differ significantly $(p=0.05)$

Statistically significant decrease of water holding capacity was observed 48 hours after slaughter. After 72 hours of ageing sample U-subjected to ultrasound treatment, was having almost two times higher water holding capacity (11.13\%) than the control sample $(5.05 \%)$. Experiments carried out 96 hours after slaughter proved further increase of water holding capacity.

During the whole period of ageing examined meat samples were characterized by similar lightness (fig. 3). Significant differences in $\mathrm{L}^{*}$ values were noted only directly after ultrasound treatment. At that time meat subjected to sonication was having higher $\mathrm{L}^{*}$ values than the control sample.

The control sample was having significantly higher shear force than the U sample 48 and 72 hours after slaughter (tab. 1). The passage of time was coupled with a decrease of this parameter for both samples.

Free calcium ions concentration was increasing during the ageing period. For U sample higher concentration of free $\mathrm{Ca}^{2+}$ was recorded at every stage of the experiment. The differences between samples were significant 72 and 96 hours after slaughter.

Вісник Дніпропетровського університету. Біологія, екологія.

Vìsnik Dnìpropetrovs'kogo unìversitetu. Serìa Bìologîa, ekologîâ Visnyk of Dnipropetrovsk University. Biology, ecology. Vìsn. Dnìpropetr. Unìv. Ser. Bìol. Ekol. 2007. 15(1).

ISSN 2310-0842 print ISSN 2312-301X online www.ecology.dp.ua 


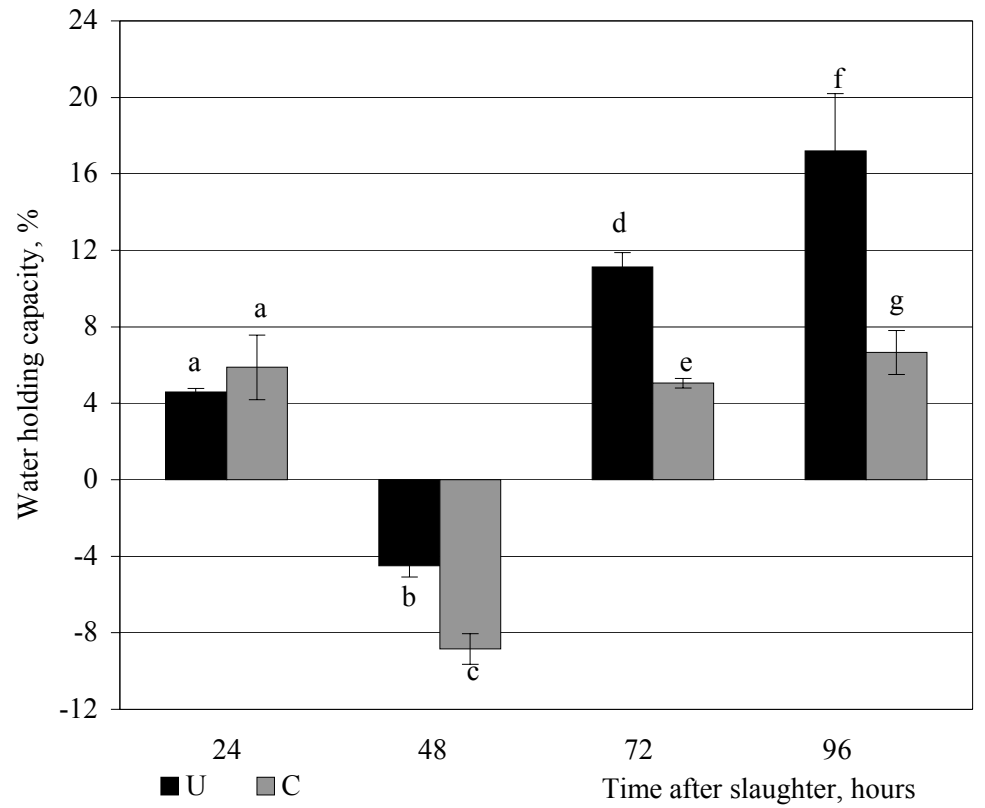

Fig. 2. Influence of ultrasound treatment on water holding capacity of meat: means followed by the same letters $a-g$ do not differ significantly $(p=0.05)$

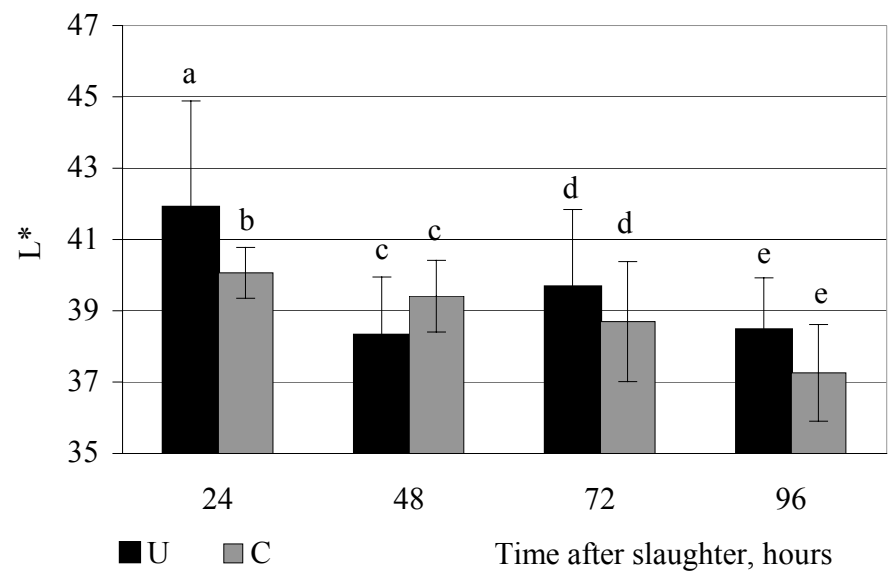

Fig. 3. Influence of ultrasound treatment on lightness of meat: means followed by the same letters $a-g$ do not differ significantly $(p=0.05)$

Influence of ultrasound treatment on shear force and free calcium ions concentration (mean \pm standard error)

\begin{tabular}{|c|c|c|c|c|c|}
\hline \multirow{2}{*}{ Sample } & \multirow{2}{*}{ Parameter } & \multicolumn{4}{|c|}{ Time after slaughter (hours) } \\
\cline { 3 - 6 } & \multirow{2}{*}{ shear force $(\mathrm{N})$} & 24 & 48 & 72 & 96 \\
\cline { 3 - 6 } $\mathrm{C}$ & $39.60 \pm 2.87^{\mathrm{a}}$ & $44.83 \pm 2.03^{\mathrm{b}}$ & $36.31 \pm 4.61^{\mathrm{d}}$ & $33.98 \pm 1.99^{\mathrm{f}}$ \\
\cline { 3 - 6 } & & $40.95 \pm 3.91^{\mathrm{a}}$ & $34.52 \pm 1.44^{\mathrm{c}}$ & $30.06 \pm 1.10^{\mathrm{e}}$ & $30.29 \pm 3.91^{\mathrm{f}}$ \\
\hline $\mathrm{U}$ & $\mathrm{Ca}^{2+}$ & $2.92 \pm 0.64^{\mathrm{a}}$ & $3.82 \pm 0.64^{\mathrm{b}}$ & $4.19 \pm 0.30^{\mathrm{c}}$ & $4.61 \pm 0.93^{\mathrm{e}}$ \\
\cline { 3 - 6 } & $(\mu \mathrm{g} / \mathrm{g})$ & $2.72 \pm 0.28^{\mathrm{a}}$ & $4.15 \pm 0.67^{\mathrm{b}}$ & $5.50 \pm 0.35^{\mathrm{d}}$ & $8.56 \pm 0.19^{\mathrm{f}}$ \\
\hline $\mathrm{U}$ & &
\end{tabular}

Means followed by the same letters $a-f$ do not differ significantly ( $p=0.05$ ) 


\section{Conclusions}

Observations of changes in protein's structures as well as previous research [1] suggest that sonication accelerates the formation of rigor mortis state of tissue. Most authors [12-14] claim that WHC changes are coupled with myofibrillar structure changes post mortem and thus meat tenderness is connected with differences in water distribution during the conversion of muscle to meat. Proteolysis of key myofibrillar and associated proteins appears to be the cause of meat tenderization [6]. Two protease systems are known: lysosomal cysteine proteinases (cathepsins) and calcium-activated proteinases, calpains [11]. According to Koohmaraie [6] calpains are the only proteases that are directly involved in the events leading to meat tenderization. Some authors claim $[16 ; 18]$ that structural changes are caused by non-enzymatic degradation of proteins in muscle cells.

According to Takahashi's theory [16] further rise of the sarcoplasmic calcium ions concentration lead to weakening structures of myofibrils, desmin intermediate filaments and probably endomysium and perimysium. In present study probably as a result of ultrasound treatment during rigor mortis period an acceleration of aging processes occurred. High values of water holding capacity obtained for sonicated sample support that hypothesis. Statistical analysis of obtained results showed no significant influence of sonication on its acidity during ageing. Differentiated technological properties of examined samples may result from influence of ultrasound on protein structures of meat.

Ultrasound treatment did not influence lightness, a very important meat quality parameter. Judging by the results of shear force measurements, sonication process has been shown to be effective at improving meat tenderness. As a result of ultrasound treatment an increase of free calcium ions concentration occurred. Obtained results pointed out that sonication may be an effective method of formation of technological properties of beef during ageing.

\section{References}

1. Dolatowski Z. J. Wpływ obróbki ultradźwiękami o niskiej częstotliwości na strukturę i cechy jakościowe mięsa // Rozprawy naukowe AR w Lublinie. - 1999. - P. 221.

2. Dolatowski Z. J. Einfluss von Ultraschall auf das Wasserbindungsvermögen von Rindfleisch / Z. J. Dolatowski, J. Twarda // Fleischwirtschaft. - 2004. - N 12. - P. 95-99.

3. Effect of high power ultrasound waves on properties of meat: a review / S. D. Jayasooriya, B. R. Bhandari, P. Torley, B. R. D'Arcy // International Journal of Food Properties. - 2004. Vol. 7, N 2. - P. 301-319.

4. Effects of high-intensity high-frequency ultrasound on ageing rate, ultrastructure and some physico-chemical properties of beef / F. Got, J. Culioli, P. Berge et al. // Meat Science. - 1999. Vol. 51. - P. 35-42.

5. Evidence against the non-enzymatic calcium theory of tenderization / G. H. Geesink, R. G. Taylor, A. E. D. Bekhit, R. Bickerstaffe // Meat Science. - 2001. - Vol. 59. - P. 417-422.

6. Koohmaraie M. Biochemical factors regulating the toughening and tenderization processes of meat // Meat Science. - 1996. - Vol. 43. - S193-S201.

7. Lyng J. G. The influence of high intensity ultrasound baths on aspects of beef tenderness / J. G. Lyng, P. Allen, B. M. McKenna // Journal of Muscle Foods. - 1997. - N 8. - P. 237-249.

8. Mason T. J. The uses of ultrasound in food technology / T. J. Mason, L. Paniwnyk, J. P. Lorimer // Ultrasonics Sonochemistry. - 1996. - N 3. - S253-S260.

9. McClements D. J. Advances in the application of ultrasound in food analysis and processing // Trends in Food Science and Technology. - 1995. - N 6. - P. 293-299.

10. Møller A. J. Myofibril fragmentation in bovine longissimus dorsi as an index of tenderness / A. J. Møller, T. Vestergaard, J. Wismer-Pedersen // Journal of Food Science. - 1973. Vol. 38. - P. 824-825.

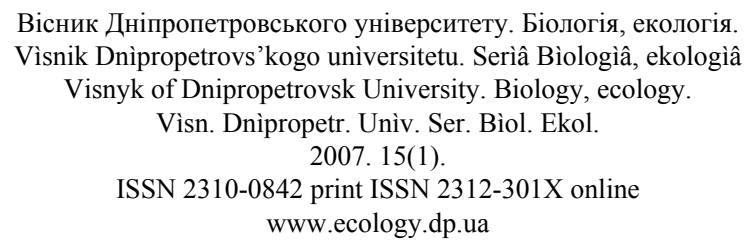


11. Muscle proteins and their changes in the process of meat tenderization / E. Pospiech, B. Grześ, A. Łyczyński et al. // Animal Science Papers and Reports. - 2003. - Vol. 21, suppl. 1. - P. 133-151.

12. Offer G. The mechanism of drip production: formation of two compartments of extracellular space in muscle post mortem / G. Offer, T. Cousins // Journal of the Science of Food and Agriculture. - 1992. - Vol. 58. - P. 107-116.

13. Physical changes of significance for early post mortem water distribution in porcine $m$. longissimus / H. C. Bertram, A. Schäfer, K. Rosenvold, H. J. Andersen // Meat Science. - 2004.Vol. 66. - P. 915-924.

14. Physiological and structural events post mortem of importance for drip loss in pork / A. Schäfer, K. Rosenvold, P. P. Purslow et al. // Meat Science. - 2002. - Vol. 61. - P. 355-366.

15. Pohlman F. W. The effect of low-intensity ultrasound treatment on shear properties, color stability and shelf-life of vacuum-packaged beef semitendinosus and biceps femoris muscles / F. W. Pohlman, M. E. Dikeman, J. F. Zayas // Meat Science. - 1997. - N 3. - P. 329-337.

16. Takahashi K. Structural weakening of skeletal muscle tissue during post mortem ageing of meat: the non-enzymatic mechanism of meat tenderization // Meat Science. - 1996. - Vol. 43. - S67-S80.

17. Twarda J. The effect of sonication on the colour and WHC of normal and PSE pork / J. Twarda, Z. J. Dolatowski // Animal Science. - 2006. - Suppl. - P. 184-185.

18. Tyszkiewicz I. Mechanizm nieproteolitycznego kruszenia mięsa wołowego // Roczniki Instytutu Przemysłu Mięsnego i Tłuszczowego. - 1969. - Vol. 6, N 1. - P. 75-93.

19. Wierbicki E. Die Bestimmung der Fleischquellung als Methode zur Untersuchung der Wasserbindungskapazitat von Muskelproteinen mit geringen salthaltevermogen / E.Wierbicki, M. G. Tiede, R. C. Burrell // Fleischwirtschaft. - 1962. - Vol. 10. - P. 948-951. 